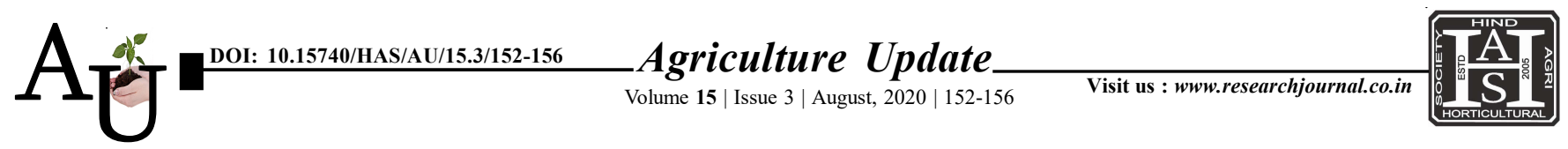

ISSN-0973-1520

\title{
Rевевсн Автіск: Study on the utilization behaviour of online journals by the students of UAS-Dharwad
}

V. A. Ramachandra, D.H. Mitrannavar and A.D. Naik

Article Chronicle :

Received :

23.12.2019;

Revised:

02.06.2020;

Accepted :

03.07.2020

KEY WoRds:

Online journals, Usage, Assignments, Problems
Author for correspondence:

\section{V.A. Ramachandra} Agricultural Economics Horticulture Research and Extension Centre, Hogalagere, Srinivaspur, Kolar (Karnataka) India Email: rama.econ@gmail. com

See end of the article for authors' affiliations
SUMMARY : The study was taken up in University Agricultural Sciences, Dharwad (UAS-D), UAS-D offered PG programme in 24 disciplines and Ph.D programme in 17 disciplines, among them 10 disciplines were selected. The sample size was 50 students consisting 30 post graduates and 20 doctoral programme students using Simple Random Sampling technique. Five students were selected from each of the 10 selected departments using simple random sampling technique. Percentage analysis was used for data analysis. About two-third of the students referred online journals for their purpose of assignment, seminar and research. Majority of the students faced the problems like getting user name, password, long time to download an article, read only content and limited availability of online journals are the major difficulties faced in access and usage of online journals. These problems could be addressed to enhance the learning of online journals among the students of UAS-D.

How to cite this article : Ramachandra, V.A., Mitrannavar, D.H. and Naik, A.D. (2020). Study on the utilization behaviour of online journals by the students of UAS-Dharwad. Agric. Update, 15(3): 152-156; DOI : 10.15740/ HAS/AU/15.3/152-156. Copyright@ 2020: Hind Agri-Horticultural Society. 